Mykola PRYMUSH

Vasyl' Stus Donetsk National University

DOI : $10.14746 /$ ps.2020.1.18

https://orcid.org/0000-0001-5769-7345

Hanna LAVRYNENKO

Borys Grinchenko Kyiv University

https://orcid.org/0000-0001-7705-6545

\title{
POLITICAL IDENTITY AS A SECURITY FACTOR OF UKRAINIAN STATEHOOD
}

The relevance of research. The inconsistent and elite-oriented policy of the Ukrainian authorities, as well as their disinterest in the real mobilization of citizens in the political process and the formation of the political identity of Ukrainians over the past two decades had provoked a number of crisis situations that exacerbated the security issue of the Ukrainian statehood. The protracted political crisis gave rise to stagnation of transformational processes in the Ukrainian state, hyper-involvement of citizens in political life, which led to the Ukrainian society fragmentation and increased the level of aggression and rejection of alternative political positions and identifications. And the state, in turn, instead of settling relations in society and forming a model of political identity for the citizens, simply withdrew, showing, on the one hand, the powerlessness to resist the growing political crises using democratic methods, and, on the other hand, the lack of interest in the formation of a stable political identity. In this connection, starting from the 2000 s, there were mass protests in Ukraine, each time plunging the country into a protracted political crisis. The negative tendency of the Ukrainian authorities to withdraw from resolving the crises existing in the state and society accumulated the dangerous potential of unresolved problems, which has finally raised the question of further existence of Ukrainian statehood.

The stalemate of current political situation in Ukraine can also be explained by the fact that at different periods of the recent history of independent Ukraine, the issue of political identification of Ukrainians became only an object of manipulation by various political forces for adjusting electoral behavior. As a result, a situational political identity, which is subjected to external influence and correlates a political position of citizens in accordance with a changing political agenda, has been formed in Ukrainian society. This type of political identity is dangerous in conditions of transforming society: it does not lead to sustainable development and stability, but is a catalyst of changes in the political situation in the short term. With regard to long-term prospects, the situational political identity becomes destructive to transforming societies and can plunge them into a protracted crisis. This is confirmed by the situation in Ukraine. Therefore, the formation of the basic political identity of Ukrainian citizens, which 
can resolve the growing crisis and become a security factor of Ukrainian statehood, is becoming more relevant than ever.

The stalemate of current political situation in Ukraine can also be explained by the fact that at different periods of the recent history of independent Ukraine, the issue of political identification of Ukrainians became only an object of manipulation by various political forces for adjusting electoral behavior. As a result, situational political identity, which is subjected to external influence and correlates a political position of citizens in accordance with a changing political agenda, has been formed in Ukrainian society. This type of political identity is dangerous in conditions of transforming society: it does not lead to sustainable development and stability, but is a catalyst of changes in the political situation in the short term. With regard to long-term prospects, the situational political identity becomes destructive to transforming societies and can plunge them into a protracted crisis. This is confirmed by the situation in Ukraine. Therefore, the formation of the basic political identity of Ukrainian citizens, which can resolve the growing crisis and become a security factor of Ukrainian statehood, is becoming more relevant than ever.

The purpose of this research is to identify a degree and nature of impact of various conditions on the process of Ukrainian citizens' political identity formation and its relation to ensuring the security of Ukrainian statehood.

In the context of this study, the author has formed a hypothesis: the formation of a basic political identity in the long term can become a factor ensuring the security of Ukrainian statehood with increased influence of civil society and minimized influence of the political elite and the media on this process. The substantiation of the hypothesis is supposed to be clearly illustrated by an example of the construction and analysis of ternary graphs.

The following approaches and research methods have been used as tools to achieve this purpose:

- the neo-institutional approach, in particular, its historical type, with the help of which the political process has been considered in the context of relations between the state and society, through actors' interpretation of the interests in the formation of political identity, access to the process of political decision-making and political representation. And the institutions themselves are interpreted as factors determining the nature of the formation of political identity. In addition, within the framework of historical neo-institutionalism, the development of civil society was investigated through the participation of the population in mass protests, as a result of which the question of political self-identification and the level of involvement in the political process was raised every time;

- the systematic and activity approaches have been used to study the problem of the formation of political identity as a complex task for the institutional components of the political system, each of which, through its functions, can affect the nature of this process and the possibility of negative consequences in the event of abuse of certain elements of its functions and powers;

- post-structuralism has been used to consider possible mechanisms of transforming a situational identity into a basic one in order to assess objectively the effectiveness of the formation of political identity and the possibility of negative consequences in the form of a crisis of statehood in the context of Ukrainian political realities; 
- the historical method has been used as a general scientific method of retrospective study of politics, in particular, of socio-political processes related to the political behavior of society and the participation of the state in the formation of political identity. Its use was aimed at studying the dynamics of the process of formation of political identity in the context of change of political and temporal conditions of the conduct of this process. It was also aimed at identification of the connection between the conduct of mass protests, the level of consolidation of society, the nature of the formation of political identity and the ensuing consequences for the security of Ukrainian statehood. In addition, the historical method was aimed at identification and scientific description of the balance of factors and conditions for the formation of political identity, focusing on which it was necessary to determine the tendencies of the conduct of this process and its consequences;

- the comparative research method with a focus on variables has been used to study the degree of impact of various factors on the process of forming the political identity of Ukrainians at different periods of time. In addition, in conducting a comparative study, a strategy of maximum similarity, based on the interconnection between surges of increased attention to the process of forming political identity and the growth of protest moods in society, which, in turn, influenced the security of Ukrainian statehood. The use of the comparative method was also aimed at solving the problem of universality in identifying the interdependence between the level and nature of the formedness of Ukrainians' political identity and the degree of security of the Ukrainian statehood.

An analysis of the literature shows that a significant number of researchers are focused on questions of the relationship between the political and social identity of an individual. These include works of A. Ben-Bassat, P. Ingle, S. Clar, C. Sander, J. Fowler, C. Devine, S. Cam, L. Haddy, M. Dahan, A. Reed, M. Hogg.

Various comparative researches of cases of political, national and civic identity are also conducted, including works of A. Bleu, M. Krochik, J. Harry, R. Nadu, E. Zhidonzhil, M. Rozema, N. Novitt, M. Sobolevskaya.

At the same time, the problem of specific features of Ukraine citizens' political identity formation, which, in turn, acts as a security factor of Ukrainian statehood, is still not sufficiently covered, which confirms the relevance of this study.

Moving to the issue of Ukrainian citizens' political identity formation, above all, it is necessary to understand that, in addition to the political identity, there are many other identities, that also have a significant and sometimes decisive influence on individual's worldview and position in socio-political life. A variety of social and political roles forces an individual to apply different forms of identity to themselves, from identification with a particular class, religious organization, profession, political party or ideology, to forms of identity related to the formation of concepts and the embodiment of innovation in the form of e-democracy and the digital market (Erikson, 1968: 136-142).

Thus, it can be stated that at the present stage an identity is presented in form of a matrix, components of which are represented by many identities that compose a certain hierarchy. Each of them has an impact on the formation of both personal orientations in socio-political space and group identification processes. In addition, the com- 
ponents of the identity matrix continuously interact with each other, complement and influence each other. Under the influence of certain circumstances, one of the forms of identities becomes dominant in the matrix hierarchy of identities. Having a prevailing influence, it begins to structure a consciousness of the individual through the information received, forming the worldview and determining the line of behavior. Thus, the dominant form of identity creates a certain prism through which the individual perceives and evaluates the surrounding processes, classifies objects and designates their roles (Huddy, 2013: 737-773).

At the same time, it should not be forgotten that the identification process is dynamic. Changing circumstances, including the emergence of crises, produce a modification in the hierarchy of identities, as a result of which another form of identity may become dominant. This leads to changes in behavior together with awareness and perception of ongoing socio-political processes.

It should be noted that the mention of various forms of identities occurs namely in the context of socio-political processes. This position is justified by the ideas of C. Walor, Canadian philosopher, according to whom any form of modern identity is inherently political. He argues his point of view by the fact that each form requires not so much universal recognition as recognition of namely those groups that were marginal to a certain degree and against which discrimination was previously applied (Taylor, 1985: 272-285).

Thus, if we start from the idea that at the present stage any form of identity is somehow involved in the political sphere or has indirect impact on it, then it becomes obvious that in forming basic political identity, it is necessary to take into account the entire matrix structure of identities, as well as the hierarchy of their relationships. If this approach is ignored, a situation of substitution of notions or, in the worst case, a crisis of statehood may occur (Hall, 1996: 1-17).

The situation in Ukraine can serve as an illustration of such a scenario of the unfolding of events. After the Revolution of Dignity in 2013-2014, a new stage of the formation of the political identity has begun in Ukrainian society. An unprecedented winning the first round of the presidential election by Petro Poroshenko showed that more than half of the population had consolidated and expressed support for change. At that time, there was an appeal in Ukrainian society for the formation of new meanings and principles of building Ukrainian statehood, a prototype of situational political identity, with required active work to become the basis for the formation of the basic political identity of Ukrainians. However, in practice, the situation ended in a diametrically opposite way. The country's leadership ignored the matrix structure of identities. Moreover, some forms of identity, in particular confessional, regional, ethnic, ideological, became an object of speculation and manipulation, which led to the aggravation of fragmentation of Ukrainian society and social conflicts. As a result, the political identity lost its dominant position, which means that the issue of the formation of basic political identity has gone into the background again. But the most dangerous is that a resurgent conflict at the level of various forms of identities caused social unrest and even a confrontation of interests in society (Semenenko, Lapkin, Pantin, 2010: 52). Thus, the inefficiency of policy of the previous government, which is confirmed by results of the presidential election in 2019 (Petro Poroshenko, incumbent President of 
Ukraine lost half the support of the electorate), led to another regression in Ukrainians' political identity formation and the actualization of the security problem of Ukrainian statehood in general.

Considering this situation from a methodological point of view, several scientific justifications for the outcome of the situation in Ukraine can be found. In particular, from the standpoint of symbolic interactionism, in the mechanism of the political identity formation emphasis is placed on the political interaction (Inaç, Ünal, 2013: 225). The reaction of the population here "is not directly caused by actions of another, but is based on the value that they attach to such actions" (Blumer, 1962: 179). Within the framework of this line, the identification process involves several levels.

At the first level, self-identification is conducted: who is who, what are positions and preferences. In the Ukrainian realities of 2013-2014, more than half of the population had a situational political identity. Ukrainians were aware of their position and role in the political process.

At the second level, direct self-designation is conducted with the help of contradistinction to representatives with different positions: the division into "us" and "them." After the situational political identity formation in Ukraine, a part of the population indicated their political preferences and aspirations, their readiness to consolidate society as a whole or within large groups in accordance with outlined lines of identification. At the same time, people with a different position were automatically identified as "them."

The third level, within the framework of symbolic interactionism, involves forming a political picture of the world, in which personal perspectives and needs for gaining and affirming one's positions are represented. With regard to the situation in Ukraine, at this level, the country's population after the Revolution of Dignity, realizing their potential, expressed desire to build a European-type state with democratic values, working political institutions, developed civil society with a high level of political culture.

At the fourth level, a comparison between the created picture of the world of the political space and real experience is performed. Then it is possible to make changes to previously created political views. In fact, it was at this stage in Ukraine that the population was disappointed in political prospects. As it turned out, the created picture of political preferences in the further development of the country did not correspond to political realities. Moreover, the political experience of Ukrainian citizens at that time demonstrated the impossibility of fundamental changes without an expression of will of the political elite. And making changes to their own created political views was amounted to a denial of the formed situational political identity. As a result, society plunged into political anomy, declared the lack of trust and illegitimacy of power. The situational political identity was not able to take root in society and develop into the basic one, and, on the contrary, it conceded dominant positions to other forms of identity, which provoked a reversal in the development of civil society, exacerbated its disunity and contributed to the growing crisis of statehood (Sobolewska, 2005: 31).

In order to evaluate objectively the effectiveness of the political identity formation in Ukrainian political realities and the possibility of negative consequences in the form 
of a crisis of statehood, it would be appropriate to consider the mechanism of situational identity transforming into the basic identity from the standpoint of post-structuralism. Within the framework of this conception (Deleuze, 1992: 5), actual political practice is directly related to the formation of situational political identity. To correct or change it, it is sufficient to use manipulative technologies to analyze the political situation and make political decisions in line with the majority positions. However, in conditions of a transformational society, an excess in the use of manipulative technologies leads to the emergence of crises.

In turn, basic political identity is related not only to particular situations, but to all available political experience. It records the importance of certain political relations. Emerging situational political identities are the basis for the basic political identity formation. They should go through the process of awareness, acceptance, differentiation and dissemination of experience in interacting with similar emerging situations. In the course of political practice, situations may be of a crisis nature, therefore, a key role in the formation of basic political identity is assigned to resolving crisis situations (McCrone, McPherson, 2009: 156-188). As a result, concepts of norms and rules of political interaction, patterns of perception and awareness, assessment and resolution of political problems are formed.

From the point of view of post-structuralists (Baudrillard, 1983), the basic political identity formation is conducted in four stages.

The first stage is the emergence of empathy for a particular political position.

The second is the formation of situational political identity on the basis of the empathy.

During the third stage, an awareness of situational political identity develops into the formation of the basic political identity.

And the fourth stage is marked by the acceptance and awareness of stable political identity.

At the same time, it is noted that under conditions of the transformation of society, the formation of basic political identity based on the situational one can lead to crisis manifestations, which happened in Ukraine.

The emergence of empathy for the events of 2013-2014 formed the situational political identity of the majority of Ukrainians. During the analysis of accumulated experience and new forms of political social relations in the process of awareness of political problems and challenges, a request for their assessment and solving, in other words, for an active political participation in the life of the state was formed. However, this request was ignored by the political elite. Moreover, the excessive use of manipulative technologies to adjust the situation for own benefits led to the rejection of the previously formed situational political identity by society. In this connection, the process of transition from situational to basic political identity was interrupted. And considering that Ukrainian society is in the process of transformation, the incompleteness of the transition process led to the emergence of new crisis spots. In particular, the level of aggression and confrontation increased both between different groups of society and in relation to power structures. Therefore, a kind of "ratification" of the lawfulness of the taking of a political position by other participants in the political process was disrupted, which provoked crisis developing. 
Given the existing political experience and having studied the significance of certain political positions for the Ukrainian society, as well as the attitude to them, it is necessary to identify and formulate criteria for constructing a basic type of political identity, the prerequisites for their formation and correlation with the real political situation in Ukraine.

The prerequisites for the formation of criteria for basic political identity are directly related to the existing experience of state functioning and the nature of interaction within society. Therefore, when formulating the criteria, it is important to cover each of spheres of life of the society, which has a direct impact on the formation of basic political identity, reflecting though different, but equivalent facets of this process (BenBassat, Dahan, 2012: 193-2014). Among the criteria for constructing a basic type of political identity, it is proposed to identify the most universal.

1) Instrumental-political criterion: each state should have a set of political instruments for influencing the formation of the political identity of citizens with the aim of society consolidation, as well as social mobilization during periods of active phases of the political struggle in order to preserve the existing political regime or to gain sustainable support from society in transformation period. The constructive use of political instruments should contribute to the de-escalation of emerging political conflicts, based on decrease in the level of legitimacy to state institutions and, in general, the rejection of government policies (Klar, 2013: 1123). Also, the qualified use of political instruments by the authorities is meant to prevent the emergence of new conflict spots, political instability and fragmentation of political attitudes in society.

2) Legal criterion: the system of legal norms developed in the state and enshrined in the Constitution and fundamental laws should contribute to the formation of political identity of citizens, the spread of unified rules of conduct and cohabitation in society under the current political regime in the state, maintaining the level of legitimacy of state institutions and the process identification of citizens (Hogg, Reid, 2006: 7-30). Legal norms should reflect the basic principles of regulation of the political life of the population, which would contribute to the consolidation of society, as well as the complete law enforcement. In addition, they should comply with the basic norms and criteria of international law. In case of non-compliance or violation of laws, a system of sanctions should be imposed.

3) Ideological criterion: in the process of forming basic political identity, the ideological component should be taken into account. The state ideology should be formulated, in which images of the past, present and future of the country are outlined, the "ultimate goal" is stated, the achieving of which the state policy is aimed at, and ideals of the development of the state and society are indicated (Devine, 2011: 196-212).

4) Moral criterion: the political identity should be constructive, stimulate society to consolidation, should not contradict established traditions and values, but, at the same time, it should meet the challenges of the present and be consistent with democratic values and principles. In society, unifying discourse, based on values and priorities acceptable to most citizens, should be spread. A system of moral principles should be created to encourage citizens to a mutually respectful attitude, tolerance, compliance with ethical standards. The state should assume the function 
of monitoring the compliance with rules and norms of behavior, as well as develop a universal socio-cultural framework for the further development of society (Fowler, Kam, 2007: 813-827).

Analyzing the effectiveness of using these criteria for constructing a basic type of political identity through the prism of correlation with the real political situation in Ukraine, a number of problematic aspects can be highlighted.

Firstly, the set of political instruments of the state influence on citizens' political identity formation used by the Ukrainian authority does not contribute to the consolidation of society, but is involved in political practice solely to mobilize the population in the pre-election period in order to prolong the existing course of development of the state. The political elite involves the masses in the political process through manipulative technologies to get maximum personal benefit, which mostly differs from the prospect of gaining the common weal for the entire population of the country. These processes give rise to an aggravation of the socio-political situation in the state, the division of society into small opposing groups, a crisis of legitimacy, which is accompanied by mass protests. The most striking examples are: the protest action "Ukraine without Kuchma" (2000-2001), the Orange Revolution (2004-2005) and the Ukrainian Revolution of Dignity (2013-2014), that led to a protracted socio-political crisis and brought into question the security of Ukrainian statehood.

Secondly, despite statements on the unification of rules and norms of behavior for all citizens of Ukraine, they still do not find a real reflection in practice. The existing system of rules of law is negated by both representatives of civil society and the top of the government. The sanctions system acts selectively, which results in further impunity. Also, the regulatory norms for democratic rights and freedoms enshrined in Ukrainian law are often neglected. Moreover, a part of the rights and freedoms that affect the confessional, cultural, historical aspect and are the basis for the formation of various forms of identity of citizens are not respected in Ukraine. Consequently, the formation of basic political identity on their ground is difficult.

Thirdly, the state, having assumed obligations to control the socio-political processes occurring in society, cannot deal with this responsibility. In Ukraine, representatives of the authorities, trying to introduce democratic principles of functioning of the state and society into political practice, ignore historically established traditions and values, which entails the rejection of innovations, political anomy and apathy, negative political identity. In addition, the absence of a single sociocultural development framework leads the fragmentation of society, increasing confrontation between various social and political groups, aggression. The experience of the past five years has shown that Ukrainian authorities, ignoring ethical standards, use moral and ethical criteria for the formation of political identity to obtain temporary benefits in form of political dividends, and not to consolidate society and create rules of coexistence acceptable to the majority. The "overtures" with separate social groups manifested in the political discourse can affect the formation of a situational political identity rather than a basic one. Moreover, in the longer term, such manipulations are fraught with the threat of an aggressive form of change of power and a crisis of statehood.

Fourthly, over 29 years of independence, single state ideology, responsible for the prospects for the further development of the country, has not been formulated 
in Ukraine. As experience shows, attempts to introduce a multidimensional political course were unsuccessful and led to the division of society into opposing groups. Also, a single image of the future of Ukraine was not formed, and political speculations about the past were used by the elite over and over again. Thus, instead of acting as the basis for the formation of the basic political identity of the citizens of Ukraine, the ideological aspect became the object of manipulation by the opposing elite groups.

The foregoing shows that the process of constructing a basic type of political identity can be successful and completed only in the case of an effective state policy and direct involvement of the state in this process (Shershenev, 1994: 12-13). The rationality of actions and abiding the criteria in the process of forming basic political identity in the long term can become the ground for further development of society and a security factor of Ukrainian statehood. Otherwise, referring to the theory of cyclical historical development (Semenenko, 2015: 173), the state will experience new crises depleting Ukraine's potential to the limit.

It is appropriate to complement the polyvariety of approaches to the study of the formation of political identity with the consideration of various models of its construction. The differentiation of models is based on the purposes pursued by political elites in the process of their political activity, the scale of programs and strategies for the formation of political identity, the level of compliance of components of strategies with existing conditions, traditions and values.

So, within the framework of the fragmental model, there is no comprehensive strategy for the formation of political identity. It consists of a number of initiatives or one-time actions, the principle of which is close to a spontaneous reaction, aimed at influencing the current situation. This model is the basis for the formation of situational political identity, because it is designed for short-term prospects. The rapid mobilization of the population, aimed at active participation in the political process, is a constructive element of its manifestation. Its destructive property is the absence of systemic attitudes and principles of interaction within society, aimed at changes in the long term. Moreover, in transformational societies this model can be "explosive," since the process of predicting the consequences of spontaneously made decisions and actions aimed at changing the conditions and principles of functioning of society becomes more complicated. It is also noted that the application of this model can be used to shift the focus from the most important problems in the state to minor ones (Abramowitz, Saunders, 2006: 176).

The popularization of memorable dates and historical events in the form of commemoration days or holiday events can be used as the most simplified examples of application of the fragmental model. During the celebrations, a surge of mass consciousness and a reduce of tension around socially significant problems are noticed. But since such actions are short-term in nature, they are not able to provide a fundamental basis for the consolidation of the population and the formation of basic political identity. Moreover, the level of dissatisfaction and tension in the society increases due to the imitational nature of these actions, which leads to a new stage of increasing distrust of the government's policies. A similar practice is common in Ukraine, where the number of commemoration days, holidays, and also attempts to sow discord in society by different interpretations of historical events or updating the discussion around controver- 
sial issues for different population groups in order to shift focus from the protracted economic crisis has increased in recent years.

Under the elite model, the implementation of a strategy for the formation of political identity is connected to the interests of authorities. This model is applied in issues of support of the existing political course or in implementation of reforms of national importance, preservation of the political regime or the status quo of certain elite groups. Any other forms of population identification except the political has a conjunctural nature or are ignored. This model compared to the previous one in terms of impact coverage is broader, more comprehensive. However, it also contributes to the consolidation of society and the formation of basic political identity to a small extent. The elite model is more effective in the context of the formation of situational identity. A distinctive feature here is the directivity of impact, namely, the activation of processes on the construction of identity from the standpoint of interested groups, which are political elites (Blais, Gidengil, Nadeau, Nevitte, 2001: 17). A negative manifestation of this model lies in the fact that the elites use a narrow circle of issues they are interested in at a certain time period, the solution of which is often not a priority for society, to form a political identity. Therefore, more global problems are silenced. Over time, the established order of things causes negative reaction in society, giving rise to a crisis of legitimacy, which can be manifested in the form of mass protests. In Ukrainian realities, the practice of using the elite model of political identity forming has been rooted a long time ago among political elites, the protests by the population of Ukraine that arise regularly are connected with it.

The organic model is the most large-scale in the context of the formation of political identity and is more directed towards the consolidation of society. It covers a wide range of areas of interaction between society and state institutions, it is characterized by consistency and duration, a high level of involvement of the state and society. Within the framework of this model, there is the greatest possibility of the formation of a basic political identity, because it is oriented to the long term. The difficulty of applying the organic model may arise due to the lack of interest among political elites to stop receiving short-term political dividends and using political technologies and manipulations in favor of project activities and strategic planning (Garry, 2007: 352). In Ukraine, this model has not been fully applied in practice yet. Separate elements in the form of projects for the strategic development of public policy and the involvement of society in the process of political decision-making were de jure developed, but de facto have never been implemented.

However, despite the many approaches, models and criteria for the political identity formation, it is necessary to state that the leading role in this process is played by the state. Indeed, it has significant resources for determining models of political identity and the mechanisms of their formation. The means of control and manipulation of civil society are at its disposal. In particular, it is about the possibility of influence on both micro- and macrocommunities (Lapkin, Pantin, 2014: 72).

In addition, the state's aspirations to exercise total control are limited not so much to the monopolization of legally used forms of violence as to the acquisition of a comprehensive legitimate symbolic power, in particular, the right to identify and establish roles in society. 
In the context of the political identity formation, the state assumes the function of disseminating the idea of the symbolic unity among citizens. This is due to the need to ensure long-term political mobilization of the population in order to maintain the existing political regime, as well as to legitimize the political system. The identity policy pursued by the state in most cases is designed to justify the need for a social partnership policy on the basis of ideological principles and to help reduce the risks of crisis situations emergence in society. The state uses national symbols, public holidays, language, etc. as the basic instruments for forming the identity policy. Legal instruments are also involved, with the help of which people are divided into "us" and "them" (Ayvazyan, 2010: 30).

The most dangerous from the point of view of preserving statehood is the loss of a balance between the constructive use of mechanisms for forming an identity policy and the excesses in the use of manipulative technologies to control society and public opinion. Otherwise, the crisis prevention policy will result in a rapid increase in confrontation within society and towards the state, which in the future will be able to lead to the levelling of the legitimacy of political institutions and the crisis of statehood in general. However, despite this, social control remains the most significant though latent function of state in the process of forming political identity.

It is noted that the main task of the state in the identity policy formation and implementation is to impose certain stereotypes on the role of the whole population and each individual separately in the political process through the activities of the political elite. The purposeful creation and further implementation of political images in political practice is the mobilization mechanism of identity as a component of the state's social control.

In order to ensure the necessary level of consent and support from the population in the process of forming a political identity, the authority seeks to settle or veil controversial issues and problems that emerge during communication with different segments of the population. The authority forms a set of models of political identity of citizens as a social control mechanism. With the help of the mass media and communication, the society is suggested variants of models approved by the political elite. Then they are integrated into the socialization process. And in case of the absence of a conflict of interest, a controlled set of models of political identity becomes socially approved.

Thus, political elites (through governance), the media and civil society become key participants in the process of forming the political identity. Depending on the aims, degree of interest and nature of the activity, each of the participants at different periods of time has a more or less significant influence on the formation of the political identity of the population and, as a result, the political behavior of citizens, which entails a number of consequences.

To illustrate the influence of key figures in the political identity formation on the civic activity of the population in different periods of the evolution of the political system of Ukraine, characterized by bursts of social activity, ternary graphs have been constructed and analyzed. Despite the obvious possibility of using such diagrams, they remained practically unused or used limitedly in political science practice. Though, the graphical information representation helps to convey an appropriate idea, reinforce the 
formulated conclusion or emphasize something. For example, H. Wainer discussed the successful use of graphs at triangular coordinates to analyze the National Assessment of Educational Progress tests for students and to illustrate the proportion of students of the corresponding educational level (Wainer, 1995: 48-54).

To build three-component diagrams that provides getting a visual picture of the change in the state of an object (citizens' activity) in three dimensions (Governance (GPA), Independent Media (IM) and Civil Society (CS)), data set of ratings of indicators of democratic development, prepared by the international non-governmental organization Freedom House was used (see Table) (Nations in Transit, 2009; Nations in Transit, 2020). The discussion on the use of Nations in Transit data is fraught with two extremes. The first is the denial of their cognitive value. The second is the exaggeration of their capabilities. The rejection of the first extreme may turn into the second, and vice versa. This is due to some limitations inherent in the study (for example, both the concept and the chosen method used in the analysis of democracy ratings are not unquestionable, but they have a right to exist, there are many examples of it) (Nisnevich, 2014).

Table 1

Values of ratings of democratic development indicators (GPA), (IM) and (CS) in Ukraine (2000-2018)

\begin{tabular}{|c|c|c|c|}
\hline Year & $\begin{array}{c}\boldsymbol{G P A} \\
\text { (Governance) }\end{array}$ & $\begin{array}{c}\boldsymbol{I M} \\
\text { (Independent Media) }\end{array}$ & $\begin{array}{c}\boldsymbol{C S} \\
\text { (Civil Society) }\end{array}$ \\
\hline 2000 & 4.75 & 5.00 & 4.00 \\
\hline 2001 & 4.75 & 5.25 & 3.75 \\
\hline 2002 & 5.00 & 5.50 & 3.75 \\
\hline 2003 & 5.00 & 5.50 & 3.50 \\
\hline 2004 & 5.25 & 5.50 & 3.75 \\
\hline 2005 & 5.00 & 4.75 & 3.00 \\
\hline 2006 & 4.50 & 3.75 & 2.75 \\
\hline 2007 & 4.75 & 3.75 & 2.75 \\
\hline 2008 & 4.75 & 3.50 & 2.75 \\
\hline 2009 & 5.00 & 3.50 & 2.75 \\
\hline 2010 & 5.00 & 3.50 & 2.75 \\
\hline 2011 & 5.50 & 3.75 & 2.75 \\
\hline 2012 & 5.75 & 4.00 & 2.75 \\
\hline 2013 & 5.75 & 4.00 & 2.75 \\
\hline 2014 & 6.00 & 4.25 & 2.50 \\
\hline 2015 & 6.00 & 4.00 & 2.25 \\
\hline 2016 & 5.75 & 4.00 & 2.25 \\
\hline 2017 & 5.75 & 4.00 & 2.50 \\
\hline 2018 & 5.75 & 4.25 & 2.75 \\
\hline & & & \\
\hline
\end{tabular}

Source: The data come from Nations in Transit-Nations in Transit 2009 (Alldata - Nations in Transit, 2000-2009), http://web.archive.org/web/20131208063353/http:/www.freedomhouse. org/report/nations-transit/2009/ukraine (24.07.2020); Nations in Transit 2020 (Alldata - Nations in Transit, 2005-2020 - EXCEL - old scale), https://freedomhouse.org/report/nationstransit (24.07.2020).

Let us assume that there is a system consisting of three components A (GPA), $\mathrm{B}$ (IM) and $\mathrm{C}(\mathrm{CS})$. In constructing a ternary graph along each of the three axes, the 
relative share of each component (for each considered option), which is limited by their total constant sum (for example, 1 or $100 \%$ ), is plotted. The shares of all indicators in the total for each value of $i$ is defined:

$$
D A_{i}=\frac{A_{i}}{\sum_{i} A_{i}} \cdot 100 \% ; \quad D B_{i}=\frac{B_{i}}{\sum_{i} B_{i}} \cdot 100 \% ; \quad D C_{i}=\frac{C_{i}}{\sum_{i} C_{i}} \cdot 100 \% .
$$

Thus, the total sum of these indicators to the value necessary to display them on a triangular diagram:

$$
D A_{i}+D B_{i}+D C_{i}=100 \% \text { (with defined value of } i \text { ). }
$$

The period from 2000 to 2018 has been chosen as the time frame of the study. To identify the tendentiousness of the influence on the process of formation of the political identity, the given time period was divided into three periods: from 2000 to 2004, from 2005 to 2013, from 2014 to 2018. This periodization is due to the most massive protests in the history of independent Ukraine. These are the protest action "Ukraine without Kuchma" in 2000-2001, the Orange Revolution in 2004-2005 and the Ukrainian Revolution of Dignity in 2013-2014, which led to several consequences (About the decision, 2015).

The first mass protests that took place in Ukraine at the end of 2000 - at the beginning of 2001 demonstrated the lack of legitimacy of the authorities in power at that time. The actions did not lead to a change of power and did not affect the identification of citizens' political "self" with other actors of the political process. At the same time, these protests became a precedent in modern Ukrainian politics, which demonstrated the potential of Ukrainian society in its ability to become active and influence political decisions and the agenda within the state, as well as the desire to declare its political positions and to form political identity.

The second mass protests of Ukrainians are known as the Orange Revolution, which prevented the transfer of power on the principle of "successor," as it had been previously implemented in the Russian Federation. The events of the Orange Revolution had radically changed the presidential election's outcome in 2004-2005 and had led to a change of the configuration of political forces, however, the situational political identity that arose in the process did not develop into a basic one.

The most massive protests in the history of independent Ukraine in 2013-2014, known as the Ukrainian Revolution of Dignity, led to a change of the ruling power and radically affected the determinated images of Ukrainian citizens "about themselves" and about their role in the political process, but further is was not supported by the newly elected government in the formation of a basic political identity.

Thus, it should be stated that during these periods, Ukraine experienced bursts of social activity, an increase in the level of population consolidation, the intensification of political identification processes and the desire to participate in political decisionmaking (Figure 1).

This triangular diagram shows that the media had a significant impact on the process of the political identity formation in Ukraine from 2000 to 2004. From the beginning of the protest actions "Ukraine without Kuchma" to the beginning of the Orange Revolution, their role was increasing every year. At the same time, as can be seen from 
Figure 1. The dynamics of the process of Ukrainian citizens' political identity formation in 2000-2004

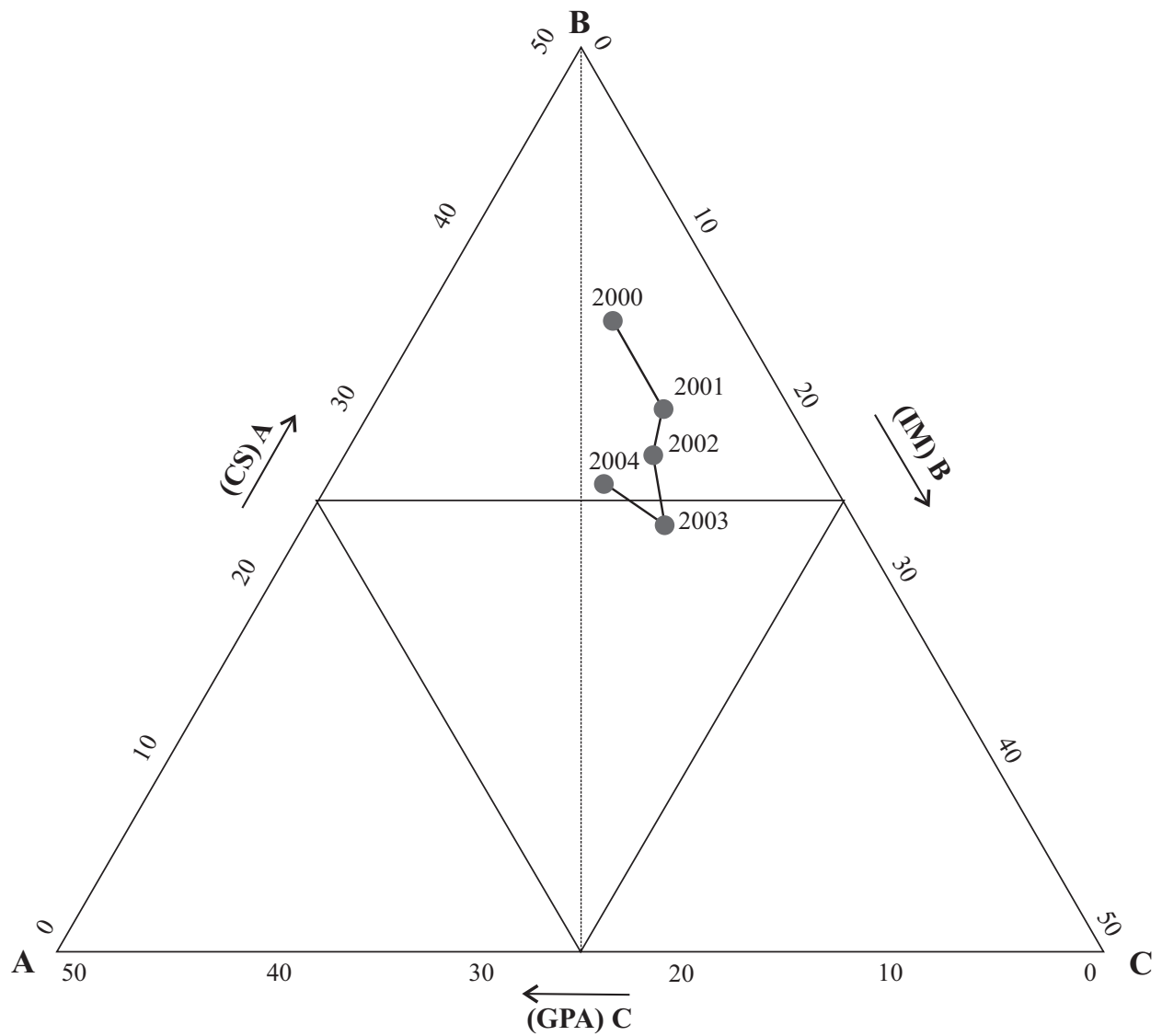

Source: Own work authors based on the data of Nations in Transit - Nations in Transit 2009, (Alldata - Nations in Transit, 2000-2009), http://web.archive.org/web/20131208063353/http://www.freedomhouse.org/report/ nations-transit/2009/ukraine (24.07.2020).

the diagram, the degree of influence of the governance nature and the activities of civil society remained the same. This situation provoked an increase in protest moods because of the rejection of the established model of political identification, which was retransmitted through the media. As a result, the protest discourse, fueled by the media, did not reduce the level of tension in society, but became the basis for the successful implementation of the Orange Revolution.

The second period can be conditionally divided into two stages (Figure 2).

The first conditional stage is characterized by an increasing influence of civil society on the process of political identity formation, which indicates minor conflicts of interest and the gradual integration of the proposed models of political identity, which were formed after the Orange Revolution, into the process of socialization. The second conditional stage demonstrates a change of tendencies, which manifested itself in the form of an increased influence of the role of political elites on the process of political 
Figure 2. The dynamics of the process of Ukrainian citizens' political identity formation in 2005-2013

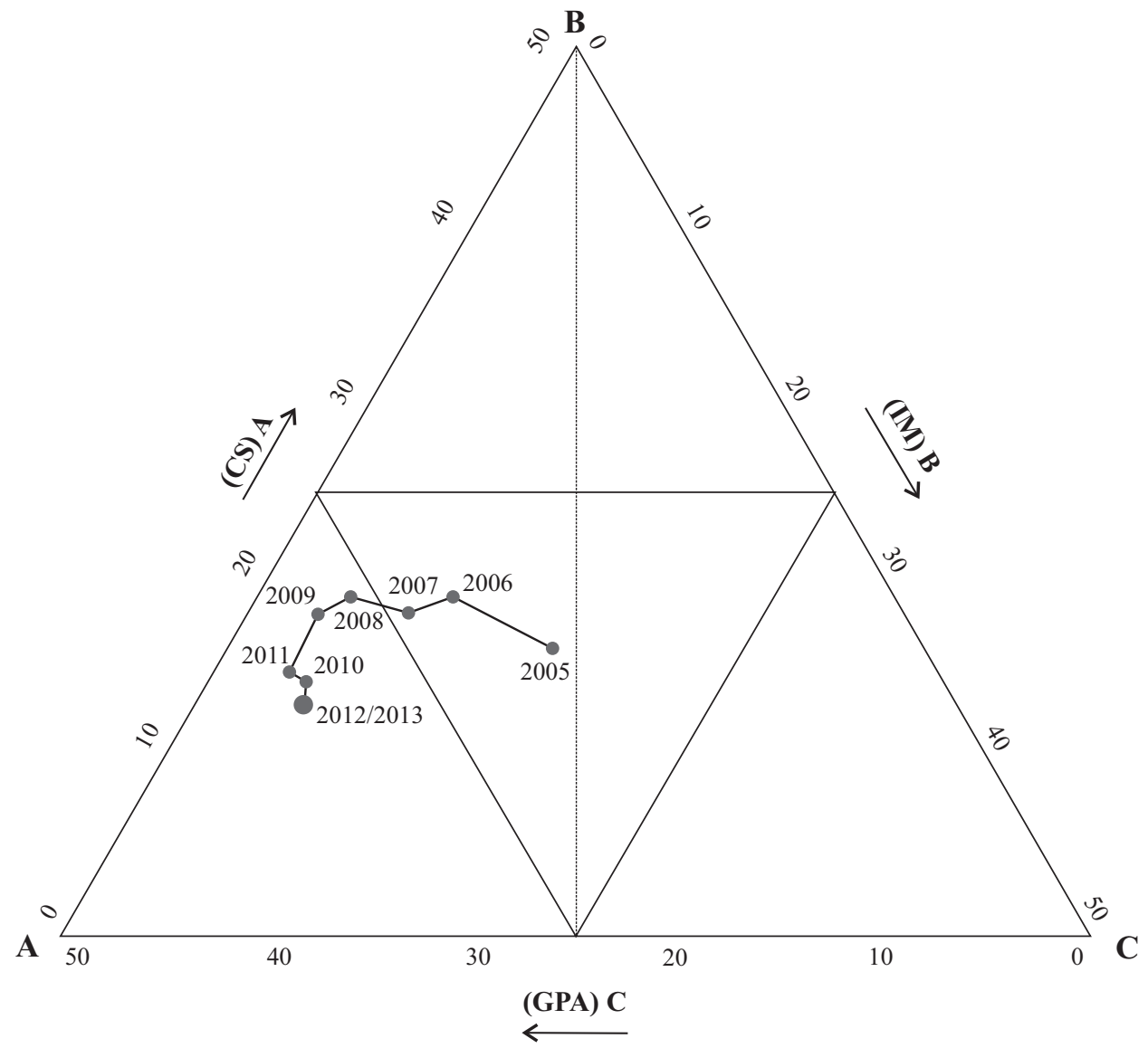

Source: Own work authors based on the data of Nations in Transit - Nations in Transit 2020 (Alldata - Nations in Transit, 2005-2020 - EXCEL - old scale), https://freedomhouse.org/report/nations-transit (24.07.2020).

identity forming, which is directly related to the nature of managing the political situation in Ukraine. Referring to historical experience, it can be stated that this particular tendency provoked a new round of rejection of the proposed model of political identity formation in society, which led to an increase in protest moods in society ended in a revolutionary change of power.

The analysis of the triangular diagram created for the third period indicates a new stage of increase in the influence of civil society on the process of political identity formation (Figure 3).

Since 2014, another opportunity for the successful political identity formation and consolidation of the population occurred in Ukrainian society. The statements made by the authorities about the formation of an updated model of political identity, proclaimed on the wave of protests, were positively received and supported by the society. And even further, an unimplemented policy and disappointed hopes that were laid on 
Figure 3. The dynamics of the process of Ukrainian citizens' political identity formation in 2014-2018

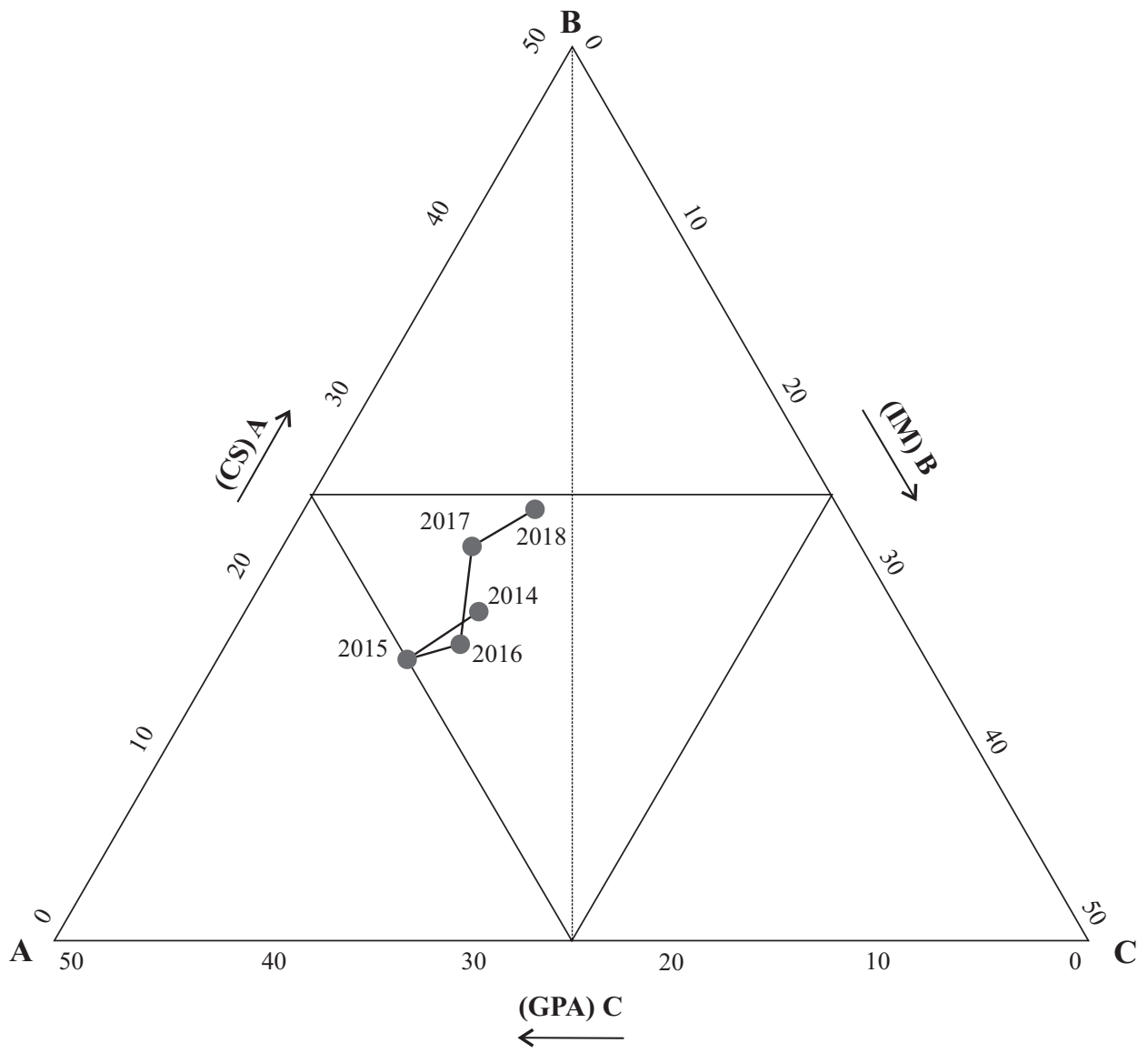

Source: Own work authors based on the data of Nations in Transit - Nations in Transit 2020, (Alldata - Nations in Transit, 2005-2020 - EXCEL - old scale), https://freedomhouse.org/report/nations-transit (24.07.2020).

Petro Poroshenko, President of Ukraine, in 2014 could not prevent the strengthening of the position of society, and, on the contrary, contributed to the consolidation and development of civil society and the political identity formation.

Thus, in the case of unhindered spread of unified rules of conduct and cohabitation, there is a perspective of embedding a controlled model of political identity approved by the society, which can contribute to maintaining the level of legitimacy of state institutions and prevent the emergence of crises of statehood. This forecast is substantiated by the results of the 2019 presidential elections, which have proved the ability of the Ukrainian population to resist manipulative technologies imposed by the pro-government elite, the desire to make decisions independently (even if it is a protest voting) and to prolong the intentions announced in 2014 to form and strengthen the renewed political identity, even after the change of power. 
As a result of the study, the hypothesis has been tested. The substantiation of the hypothesis has revealed the following pattern: when the influence of civil society on the process of political identity formation strengthens, the controlled model of political identity previously approved by society will contribute to maintain the level of legitimacy of state institutions and prevent the emergence of crises of statehood, preceded by bursts of protests. In the case of an increase in the influence of the political elite and the media on the process of political identity formation, society's rejection of the controlled model of political identity proposed by the elite, which will be accompanied by an increase in protest moods in society, a growing crisis of the legitimacy of state institutions, which may ultimately become a threat to statehood, should be expected.

In addition, two main tendencies are clearly visible. The first lies in the fact that after the growth of protest moods, which are accompanied by mass actions and lead to a regime change, a "thaw" begins in the public mood and behavior. It is expressed through the form of a positive perception of models of the formation of political identity proposed by the political elite with their gradual integration into the process of socialization. This pattern demonstrates universalism in issues of the formation of political identity. This refers to the priority of involving civil society in the process of political identification and the need to coordinate models of political identity proposed by the political elite. In the case of ignoring this pattern, the threat of a crisis of statehood becomes inevitable.

The second pattern is manifested in the revealed tendentiousness of the influence of the media and political elites on the security level of Ukrainian statehood. In particular, this concerns ignoring the interests of civil society and the politically committed influence of these participants in the process of forming political identity, which contributes to the increasing a level of tension in society, rejecting the proposed model of political identification, emergence of new protests.

In conclusion, it is necessary to caution about the importance of compliance with the above recommendations in the process of forming the political identity. Excesses in the interests of political groups representing state power can lead to the loss of legitimacy to political institutions, the emergence of protest movements and the growing crisis of statehood. The most exposed to such scenarios are states that are at the stage of transformation. In particular, this also concerns Ukraine. According to the results of the analysis, the formation of the political identity is the important security factor of Ukrainian statehood, stability of development and consolidation of society. And, therefore, it should become a priority of state policy of Ukraine.

\section{REFERENCES}

About the decision of the National Security and Defense Council of Ukraine on May 6, 2015 "On the National Security Strategy of Ukraine”, https://zakon5.rada.gov.ua/laws/show/287/2015 (15.07.2020).

Abramowitz A. I., Saunders K. L. (2006), Exploring the Basis of Partisanship in the American Electorate: Social Identity vs. Ideology, "Political Research Quartely", Vol. 59, No. 2. 
Ayvazyan G. A. (2010), Political identity as an analytical tool of political science, "Society and power", No. 3.

Baudrillard J. (1983), In the Shadow of the Silent Majority - Or the End of the Social, Semiotext(e), New York, NY.

Ben-Bassat A., Dahan M. (2012), Social Identity and Voting Behavior, "Public Choice", Vol. 151.

Blais A., Gidengil E., Nadeau R., Nevitte N. (2001), Measuring Party Identification: Britain, Cana$d a$, and the United States, "Political Behavior", Vol. 23, No. 1.

Blumer H. (1962), Society as symbolic interaction, in: Human Behavior and Social Processes, (ed.)

A. Rose, Houghton Mifflin Co, Boston.

Deleuze G. (1992), Postscript on the societies of control, "October", Vol. 59.

Devine C. J. (2011), Ideological Social Identity: How Psychological Attachment to Ideological Groups Shapes Political Attitudes and Behaviors, The Ohio State University, Columbus.

Erikson E. H. (1968), Identity: youth and crisis, W.W. Norton, New York, NY.

Fowler J. H, Kam C. D. (2007), Beyond the Self: Social Identity. Altruism, and Political Participation, "The Journal of Politics", Vol. 69, No. 3.

Garry J. (2007), Making «Party Identification» More Versatile: Operationalising the concept for the multiparty setting, "Electoral Studies", Vol. 26, No. 2, DOI: 10.1016/j.electstud.2006.07.003.

Hall S. (1996), Introduction. Who Needs «Identity»?, in: Questions of cultural identity, (eds.) S. Hall, P. Du Gay, Sage, London.

Hogg M. A., Reid S. A. (2006), Social Identity, Self-Categorization, and the Communication of Group Norms, "Communication Theory", No. 16.

Huddy L. (2013), From group identity to political cohesion and commitment, in: The Oxford handbook of political psychology, (eds.) L. Huddy, D. O. Sears, J. S. Levy, Oxford University Press.

Inaç H., Ünal F. (2013), The construction of national identity in modern times: Theoretical perspective, "International journal of humanities and social science", Vol. 3, No. 11.

Klar S. (2013), The Influence of Competing Identity Primes on Political Preferences, "The Journal of Politics", Vol. 75.

Lapkin V. V., Pantin V. I. (2014), The crisis of Ukrainian statehood: political and legal, value and geoeconomic aspects, "Polis. Political Studies”, No. 5, DOI: 10.17976/jpps/2014.05.00.

McCrone D., McPherson G. (eds.) (2009), National Days. Constructing and Mobilising National Identity, Palgrave Macmillan, London.

Nations in Transit 2009, (Alldata - Nations in Transit, 2000-2009), http://web.archive.org/ web/20131208063353/http://www.freedomhouse.org/report/nations-transit/2009/ukraine (24.07.2020).

Nations in Transit 2020, (Alldata - Nations in Transit, 2005-2020 - EXCEL - old scale), https:// freedomhouse.org/report/nations-transit (24.07.2020).

Nisnevich Yu. A. (2014), World development indices, (eds.) Yu. A. Nisnevich, O. T. Gasparyan, R. U. Kamalova, E. A. Kocheshkova, Higher School of Economics, Moscow.

Semenenko I. S. (2015), Evolutionary cycles and problems of forecasting political changes, "Polis. Political Studies", No. 1, DOI: 10.17976/jpps/2015.01.15.

Semenenko I. S., Lapkin V. V., Pantin V. I. (2010), Identity in the system of coordinates of the world development, "Polis. Political Studies", No. 3.

Shershenev L. I. (1994), Safety: state and public foundations, "Safety”, No. 4(20).

Sobolewska M. (2005), Ethnicity as a Political Clevage: Social Basis of Party Identity and Relevance of Political Attitudes, "Working paper Series", No. 107. 
Taylor C. (1985), Philosophy and the Human Sciences, Cambridge University Press. Wainer H. (1995), Visual revelations, "Chance", No. 8.

\begin{abstract}
In the article, the authors analyze the formation of the political identity of citizens of Ukraine as a security factor of Ukrainian statehood. It is noted that, in addition to political identity, there are many other identities, that are presented in the form of a matrix, the components of which continuously interact with, complement and influence each other. In terms of methodology, the process of forming political identity is considered from the standpoint of symbolic interactionism, where the emphasis is placed on political interaction. In addition, in order to objectively assess the effectiveness of the formation of political identity and potential negative consequences in the form of a crisis of statehood, the mechanism for transforming a situational identity into a basic political identity is considered from the standpoint of post-structuralism. The study identifies and formulates criteria for constructing this basic type of political identity, the prerequisites for their formation and correlation with the actual political situation in Ukraine. The multitude of approaches to the study of the formation of political identity is complemented by the consideration of various models of its construction. Fragmental, elite and organic models are considered. Particular attention is paid to the leading role of the state in the process of forming political identity, where the key participants are political elites, the media and civil society. To determine how the perception of the degree of influence of each participant affects the process of political identity formation by the population of Ukraine at different periods of time, with its intermittent outbursts of social activity, the method of factor analysis is used. On the basis of the results of the analysis of the constructed triangular diagrams, two patterns are extracted. According to one, an increase in positive perception and integration into the process of socialization of models of the political identity formation proposed by the political elite is observed in society after each surge in mass protests that leads to a regime change. The other pattern is manifested in the revealed tendentiousness of the influence of the media and political elites on the security level of Ukrainian statehood and the growth of tension in society.
\end{abstract}

Key words: political identity, crisis of statehood, security, civil society, universalism

\title{
TOŻSAMOŚĆ POLITYCZNA JAKO CZYNNIK BEZPIECZEŃSTWA PAŃSTWOWOŚCI UKRAIŃSKIEJ
}

\section{STRESZCZENIE}

W artykule autorzy analizują kształtowanie się tożsamości politycznej obywateli Ukrainy będącej czynnikiem bezpieczeństwa państwowości ukraińskiej. Podkreślono, że oprócz tożsamości politycznej istnieje wiele innych tożsamości przedstawionych tutaj w postaci matrycy, której składniki nieustannie oddziałują ze sobą, uzupełniają się i wpływają na siebie nawzajem. W ujęciu metodologicznym proces kształtowania się tożsamości politycznej rozpatruje się z punktu widzenia interakcjonizmu symbolicznego, w którym nacisk kładzie się na interakcję polityczną. Dodatkowo, aby obiektywnie ocenić skuteczność kształtowania się tożsamości politycznej i potencjalne negatywne konsekwencje w postaci kryzysu państwowości, mechanizm przekształcania tożsamości sytuacyjnej w podstawową tożsamość polityczną rozpatrywany jest z punktu widzenia poststrukturalizmu. Opracowanie identyfikuje i formułuje kryteria konstru- 
owania tego podstawowego typu tożsamości politycznej, przesłanki ich kształtowania i korelacje z aktualną sytuacją polityczną na Ukrainie. Uzupełnieniem wielości podejść do badań kształtowania się tożsamości politycznej jest uwzględnienie różnych modeli jej konstrukcji. Pod uwagę brane są modele fragmentaryczne, elitarne i organiczne. Szczególną uwagę zwraca się na wiodącą rolę państwa w procesie kształtowania tożsamości politycznej, którego kluczowymi uczestnikami są elity polityczne, media i społeczeństwo obywatelskie. Aby określić, w jaki sposób postrzeganie stopnia wpływu każdego uczestnika przekłada się na proces kształtowania się tożsamości politycznej przez mieszkańców Ukrainy w różnych okresach, z jej okresowymi wybuchami aktywności społecznej, posłużono się metodą analizy czynnikowej. Na podstawie wyników analizy stworzonych w pracy diagramów trójkątnych wyodrębniono dwa wzory. Według jednego z nich, po każdym nasileniu masowych protestów prowadzących do zmiany reżimu obserwuje się w społeczeństwie wzrost pozytywnego postrzegania i nasilenie procesu socjalizacji modeli formowania się tożsamości politycznej proponowanych przez elity polityczne. Drugi wzorzec przejawia się w stwierdzonej tendencyjności wpływu mediów i elit politycznych na poziom bezpieczeństwa ukraińskiej państwowości oraz narastaniu napięcia w społeczeństwie.

Słowa kluczowe: tożsamość polityczna, kryzys państwowości, bezpieczeństwo, społeczeństwo obywatelskie, uniwersalizm 